\title{
Subcutaneous Connective Tissue Response to Primary Root Canal Filling Materials
}

\author{
Alexandra Mussolino de QUEIROZ \\ Sada ASSED \\ Alberto CONSOLARO \\ Paulo NELSON-FILHO \\ Mario Roberto LEONARDO \\ Raquel Assed Bezerra SILVA \\ Lea Assed Bezerra SILVA \\ Department of Pediatric Clinics, Preventive and Community Dentistry, Ribeirão Preto Dental School, \\ University of São Paulo, Ribeirão Preto, SP, Brazil
}

\begin{abstract}
This study evaluated the response of the subcutaneous connective tissue of BALB/c mice to root filling materials indicated for primary teeth: zinc oxide/eugenol cement (ZOE), Calen paste thickened with zinc oxide (Calen/ZO) and Sealapex sealer. The mice ( $\mathrm{n}=102)$ received polyethylene tube implants with the materials, thereby forming 11 groups, as follows: I, II, III: Calen/ZO for 7, 21 and 63 days, respectively; IV, V, VI: Sealapex for 7, 21 and 63 days, respectively; VII, VIII, IX: ZOE for 7, 21 and 63 days, respectively; X and XI: empty tube for 7 and 21 days, respectively. The biopsied tissues were submitted to histological analysis (descriptive analysis and semiquantitative analysis using a scoring system for collagen fiber formation, tissue thickness and inflammatory infiltrate). A quantitative analysis was performed by measuring the area and thickness of the granulomatous reactionary tissue (GRT). Data were analyzed by Kruskal-Wallis, ANOVA and Tukey's post-hoc tests $(\alpha=0.05)$. There was no significant difference $(\mathrm{p}>0.05)$ among the materials with respect to collagen fiber formation or GRT thickness. However, Calen/ZO produced the least severe inflammatory infiltrate ( $<<0.05$ ). The area of the GRT was significantly smaller $(\mathrm{p}<0.05)$ for Calen/ZO and Sealapex. In conclusion, Calen/ZO presented the best tissue reaction, followed by Sealapex and ZOE.
\end{abstract}

Key Words: root filling materials, primary teeth, tissue response, subcutaneous tissue.

\section{INTRODUCTION}

In primary teeth with irreversible inflammatory pulpal alterations or pulp necrosis with or without apical periodontitis, the endodontic treatment consists of biomechanical root canal preparation and obturation with phagocytable materials (1). In these cases, tissue compatibility is one of the most important requisites because root canal filling materials for primary teeth are placed in developing organisms $(2,3)$, and remain in intimate contact with apical and periapical tissues, especially during physiological root resorption, and with the germ of the permanent successor (4).

Several materials have been proposed for root canal filling in primary teeth, the most commonly used being zinc oxide and eugenol cement (ZOE). However, this material may unchain a chronic inflammatory reaction in the periapical tissues (2) and has low phagocytability, leaving material particles in the periapical tissues, even with the progress of physiological root resorption (5).

Sealapex (Sybron-Kerr, Romulus, MI, USA) is a calcium hydroxide-based sealer with recognized biocompatibility that is widely used in permanent teeth (68 ). More recently this material has also been indicated for primary teeth with clinical and radiographic success (3).

Calen paste [S.S. White Artigos Dentários Ltda, Rio de Janeiro, RJ, Brazil; composition: $2.5 \mathrm{~g} \mathrm{CH}, 0.5 \mathrm{~g}$ zinc oxide, $0.05 \mathrm{~g}$ colophony and $1.75 \mathrm{~mL}$ polyethylene glycol 400 (vehicle)] is a commercial calcium hydroxidebased material for use as a root canal dressing, which has recognizably good tissue tolerance $(9,10)$, even when associated with chlorhexidine (11). The use of Calen paste thickened with zinc oxide (Calen/ZO) as a root canal filling material for primary teeth has

Correspondence: Profa. Dra. Alexandra M. de Queiroz, Departamento de Clínica Infantil, Odontologia Preventiva e Social, Faculdade de Odontologia de Ribeirão Preto, USP, Avenida do Café, S/N, 14040-904 Ribeirão Preto, SP, Brasil. Tel: +55-3602-4116. Fax: +55-16-3633-0999. e-mail: amqueiroz@forp.usp.br 
recently been proposed (12). The addition of ZO aims at reducing the velocity of paste phagocytosis, which should accompany the physiological resorption of the roots of the primary teeth (11). This paste also has high antibacterial activity (13).

This study evaluated the response of the subcutaneous connective tissue of isogenic BALB/c mice to the implantation of polyethylene tubes filled with ZOE, Sealapex and Calen/ZO.

\section{MATERIAL AND METHODS}

All experiments were approved by the Animal Care and Use Committee of the Dental School of Ribeirão Preto, University of São Paulo, Brazil (Protocol number 07.1.124.53.0) in compliance with the applicable ethical guidelines and regulations of the International Guiding Principles for Biomedical Research Involving Animals. The study design and parameters for tissue reaction evaluation were in accordance with the ISO 10993-6 (1994) standard (14).

One hundred and two male isogenic BALB/c mice aged 6-8 weeks and weighing 15 to $20 \mathrm{~g}$ were obtained from the Laboratory Animal Care Facility of the Medical School of Ribeirão Preto, Brazil, and were randomly assigned to 11 groups. Each animal received one polyethylene tube implant $(10 \mathrm{~mm}$ long x $1 \mathrm{~mm}$ diameter) on the dorsal region, filled with one of the tested materials (experimental groups) or an empty polyethylene tube (controls groups). Distribution of the animals in the groups were as follows: Groups I, II, III: Calen/ZO for 7, 21 and 63 days, respectively; Groups IV, V, VI: Sealapex for 7, 21 and 63 days, respectively; Groups VII, VIII, IX: ZOE for 7, 21 and 63 days, respectively; Groups X and XI: empty tube for 7 and 21 days, respectively. Groups I to IX had 10 animals each, while Groups X and XI had 6 animals each.

All tubes had their ends closed by using sterile heated clinical tweezers, and were then sterilized with ethylene oxide, and filled with the materials under aseptic conditions in a laminar flow chamber immediately prior to use and implantation. The commercial materials were mixed according to the manufacturers' instructions. Calen/ZO was prepared by mixing $1 \mathrm{~g}$ of Calen paste with $0.65 \mathrm{~g}$ of $\mathrm{ZO}$ on a sterile glass plate.

Before tube implantation, the animals were anesthetized with an intraperitoneal injection of $10 \%$ chloral hydrate $(1 \mathrm{~mL} / 100 \mathrm{~g}$ body weight), and had the dorsal region shaved and cleaned with a $1 \%$ chlorhexidine solution (Farmoderm, Ribeirão Preto, SP, Brazil). A 1-cm-wide incision was made on the dorsal region followed by tissue divulsion with Kelly forceps, and the tube was inserted into the connective tissue and the skin borders were closed with 4-0 silk sutures (Vicryl; Johnson \& Johnson: Ethicon Inc., New Brunswick, NJ, USA). The surgery was performed under aseptic conditions to minimize the trauma to the implant area. The animals were kept with free access to standard chow and water during the experimental periods and were periodically observed for local, systemic and behavioral abnormalities.

At the end of each experimental period, 10 animals of each experimental group (7, 21 and 63 days) and 6 animals of each control group (7 and 21 days) were anesthetized again for careful removal of the implant together with the surrounding tissues (skin and subcutaneous connective tissue) and were then sacrificed by anesthetic overdose. The biopsied tissues were fixed in $10 \%$ buffered formalin solution for $48 \mathrm{~h}$ and then subjected to routine processing for histological analysis. Serial 4-5- $\mu \mathrm{m}$-thick sections were made parallel to the tube long axis and stained with hematoxylin and eosin. The specimens were examined by a trained pathologist with a light binocular microscope (Olympus, Tokyo, Japan) at $\times 4,10,40$, and 100 magnifications. Descriptive (qualitative), semi-quantitative and quantitative microscopic analyses of tissue reaction to the tested materials and the empty tubes at the different experimental periods were done.

In the semi-quantitative microscopic analysis, performed as described by Silva et al. (11), four-point (03) scoring systems were used to evaluate the tissue around the implants, according to the following parameters: Collagen fiber formation (number and density of collagen fibers permeating peripheral cells located within the reactionary granulomatous tissue (RGT) surrounding the material tested): score $0=$ absent; score $1=$ mild: individual collagen fiber arrangement resembling a normal connective tissue, permeated by negative spaces indicative of non-fibrous components of the extracellular matrix; score 2 = moderate: areas with individual collagen fibers alternated with areas of eosinophilic extracellular matrix without typical linear and undulate formations; and score 3 = intense: collagen fibers merged within an eosinophilic extracellular matrix without the typical linear and undulate formations, not allowing to distinguish the individual fibers; Inflammatory infiltrate ( concentration of polymorphonuclear neutrophils - PMN 
- permeating the reactionary tissue surrounding the implanted material): score $0=$ absent; score $1=$ mild $(1$ to $10 \mathrm{PMN})$; score $2=$ moderate $(11$ to $20 \mathrm{PMN})$; and score $3=$ intense $(>21 \mathrm{PMN})$.

For the quantitative microscopic analysis, the area $\left(\mu \mathrm{m}^{2}\right)$ and the region of greatest thickness $(\mu \mathrm{m})$ of the RGT formed at the tube ends were measured. The microscopic images were captured and transferred to image-analysis software ( $\mathrm{J} 1.28 \mathrm{u}$, National Institute of Health, Staten Island, NY USA).

Higher scores related to collagen fibers formation, and inflammatory infiltrate, represented the worst tissue compatibility of the materials. Also, increased values of area and thickness of RGT were considered.

Results from the semi-quantitative and quantitative analyses were analyzed statistically using Graph Pad Prism 4 statistical software (Graph Pad Software Inc., San Diego, CA, USA). Data from collagen fiber formation and inflammatory infiltrate were analyzed by the Kruskal-Wallis test, while data from the area and the greatest thickness of the RGT were analyzed by Kruskal-Wallis, ANOVA and Tukey's post-hoc tests A significance level of 5\% was set for all analyses.

\section{RESULTS}

\section{Descriptive Microscopic Analysis}

Group I (Calen/ZO - 7 days) (Fig. 1A and B): The tissue reaction at the interface between the material and the surrounding connective tissue was characterized by a thin, homogeneous zone of eosinophilic tissue. Macrophage infiltration could be seen underneath this tissue, with well organized foci of fibroblasts and areas with inflammatory multinucleated foreign body giant cells (GC). Several PMN were seen permeating the zone of tissue reaction. There was focal collagen fiber formation without the formation of a characteristics continuous and well organized capsule.

Group II (Calen/ZO - 21 days) (Fig. 1C and D): There was moderate collagen fiber formation, with welldefined capsular organization, several macrophages, mild edema and number of PMN ranging from mild to moderate. Some GC were also seen. There was increase in collagen fiber formation as well as improvement of capsular organization and decrease of edema and leukocyte infiltration, especially macrophages.

Group III (Calen/ZO - 63 days) (Fig. 1E and F): The tissue reaction was thinner and very well organized.
Collagen fiber formation ranged from mild to moderate; the mild collagen fiber formation was similar to that of the surrounding tissues. The number of PMN and GC was significantly low.

Group IV (Sealapex Sealer - 7 days) (Fig. 2A and B): At the interface with the material there was a homogenous hyaline area, with cellular fragmentation and mild edema. Underneath this area, there were several PMN, macrophages and young fibroblasts. Mild collagen fiber formation predominated in some specimens.

Group V (Sealer Sealapex - 21 days) (Fig. $2 \mathrm{C}$ and $\mathrm{D}$ ): The zone of tissue reaction was thin and presented a mild to moderate well organized collagen fiber formation. Mild edema and neutrophil response were observed. The macrophages presented dark birefringent engulfed sealer particles in their cytoplasm. These particles were also abundantly observed in the cytoplasm of GC.

Group VI (Sealer Sealapex - 63 days) (Fig. 2E and F): Moderate well organized collagen fiber formation was observed. Macrophages were phagocyting material particles and were diffusively distributed within the reactionary tissue. The PMN were found in a large number and some GC were also present. The zone of tissue reaction was thin.

Group VII (ZOE - 7 days) (Fig. 3A and B): At the interface with the material, the reactionary tissue did not present an eosinophilic area, and the cell types were PMN, in a large number, macrophages and fibroblasts. Mild edema and collagen fiber formation were observed with well defined capsular organization. GC were present in a large number.

Group VIII (ZOE - 21 days) (Fig. 3C and D): The reactionary tissue was moderately thick with good capsular organization. The fibroblasts were well defined, fusiform and were arranged continuously with collagen fibers. A small number of PMN was present. In some specimens, the macrophages presented engulfed sealer particles in their cytoplasm. Some GC were observed.

Group IX (ZOE - 63 days) (Fig. 3E and F): The zone of reactionary tissue was thinner than at 7 and 21 days. Collagen fiber formation was mild and well organized. No macrophages phagocytizing material particles were seen. Some GC were present. The PMN were present in a considerable number and were more numerous than at 21 days.

Group X (Empty tube - 7 days) (Fig. 4A and $\mathrm{B})$ : The tissue reaction at the tube end was represented by the marked presence of fibroblasts permeated by 
macrophages and occasional PMN. No GC were found. At the lateral tube walls the tissue response was less exuberant, with few GC and macrophages. In terms of collagen fiber formation and structural organization, the morphology of the reactionary tissue was close to that of fibrous connective tissue.

Group XI (Empty tube - 21 days) (Fig. 4C and D): The thickness of the reactionary tissue at the tube end was less exuberant when compared to the 7-day period, but with less intense collagen fiber formation. The macrophages were associated with occasional PMN and GC. Compared to the lateral walls of the implanted tube, tissue response at the empty tube end was more intense in terms of thickness and number of cells.

\section{Semi-Quantitative Microscopic Analysis}

The distribution of the scores obtained after evaluation of the collagen fiber formation and inflammatory infiltrate for the tested materials at the different experimental periods is presented in Figure 5 (A and B, respectively).

Regarding collagen fiber formation, at 7 days, the control group presented greater collagen fiber formation (Fig. 5A), but differed significantly $(\mathrm{p}<0.05)$ only from Sealapex. At the 21-day period, greater collagen fiber
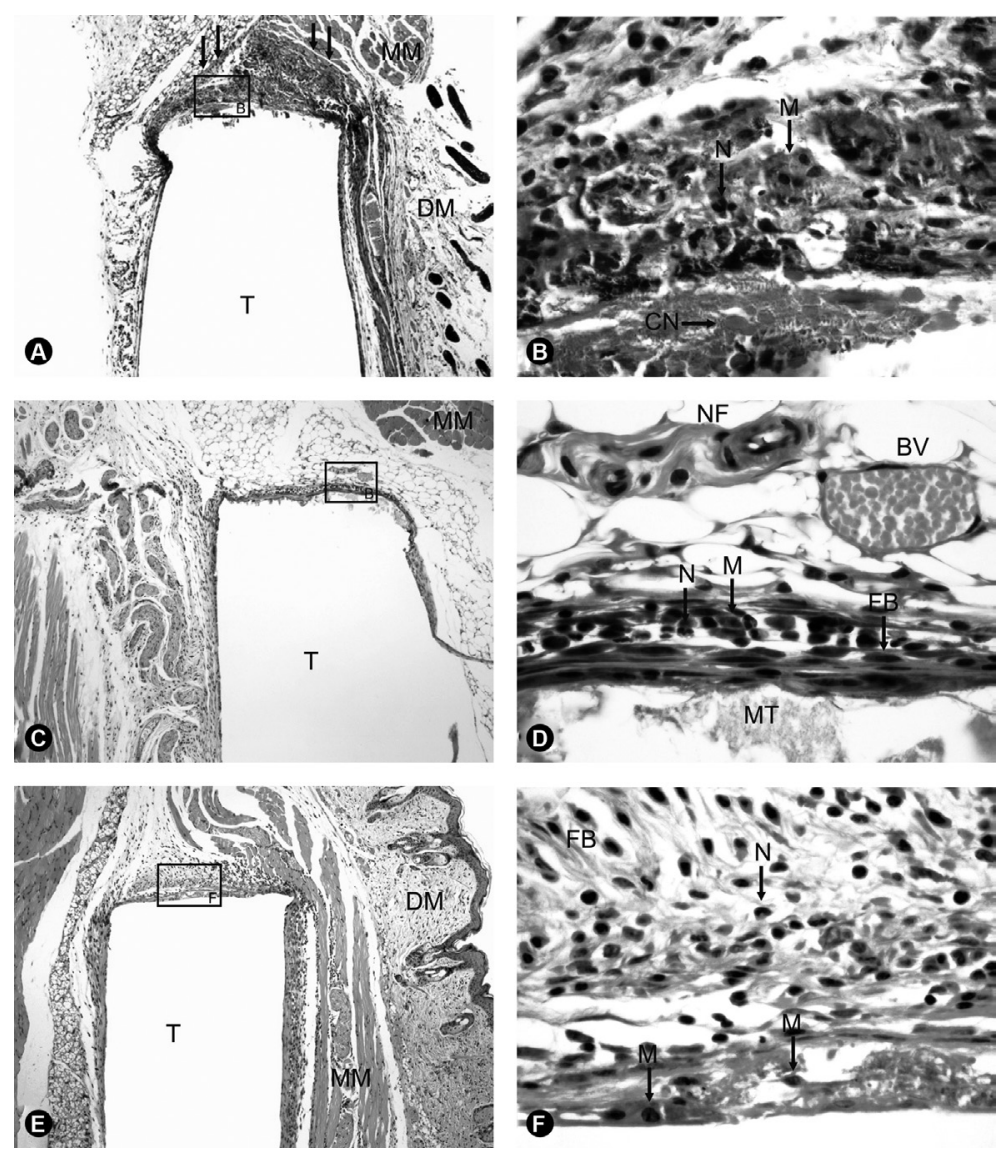

Figure 1. Calen/ZO: A and B = At 7 days, macrophages (M), fibroblast bundles (arrows in A), polymorphonuclear neutrophils (N) and areas of coagulation necrosis $(\mathrm{CN})$ were observed (HE; $\mathrm{A}=\times 4$ and $\mathrm{B}=\times 100$ ). $\mathrm{C}$ and $\mathrm{D}=\mathrm{At} 21$ days, moderate collagen fiber formation was observed, with well organized collagen bundles and well defined capsular organization at the interface with the material (in C). Macrophages (M) can be seen among the fibroblasts (FB) as well as mild edema (represented by the spaces negative) and occasional polymorphonuclear neutrophils $(\mathrm{N})$. Discrete presence of granular, homogeneous and eosinophilic material particles was observed (HE; $\mathrm{C}=\times 4$ and $\mathrm{D}=\times 100$ ). $\mathrm{E}$ and $\mathrm{F}=\mathrm{At} 63$ days, mild collagen fiber formation was seen, with poorly organized short and well defined collagen bundles and no evident capsular organization at the interface with the material. Macrophages (M) can be seen among the fibroblasts (FB), even close to the material, as well as mild edema (represented by the spaces negative) and occasional polymorphonuclear neutrophils $(\mathrm{N})$. ( $\mathrm{HE} ; \mathrm{E}=\times 4$ and $\mathrm{F}=\times 100)$. T= Polyethylene tube; MT=Material; MM= Skeletal muscle; $\mathrm{DM}=$ Dermis; $\mathrm{NF}=$ Neural fiber bundle; $\mathrm{BV}=$ Blood vessel. 
formation was observed in response to Calen/ZO and Sealapex, though without significant difference $(\mathrm{p}>0.05)$ between them. There was significant difference $(p<0.05)$ between all tested materials and the control and between Calen/ZO and ZOE $(\mathrm{p}<0.05)$. At 63 days, the analysis of data showed significant difference $(\mathrm{p}>0.05)$ among all tested materials.

Regarding the inflammatory infiltrate (Fig. 5B), at 7 days, there was significant difference between all tested materials and the control $(\mathrm{p}<0.05)$, and Calen/ZO produced an inflammatory infiltrate of lower intensity than the other tested materials $(\mathrm{p}<0.05)$. At 21 days, there was statistically significant difference between all tested materials and the control $(\mathrm{p}<0.05)$, which showed no inflammatory infiltrate in most specimens. However, no statistically significant difference $(p>0.05)$ was found when the tested materials were compared to each other. At 63 days, Calen/ZO produced a less severe $(\mathrm{p}<0.05)$ inflammatory infiltrate than the other tested materials.

\section{Quantitative Microscopic Analysis}

The mean values and standard deviations of the area and greatest thickness of the RGT at the tube end in the different groups are presented on Table 1.

Regarding the area (Table 1), at the 7-day period,

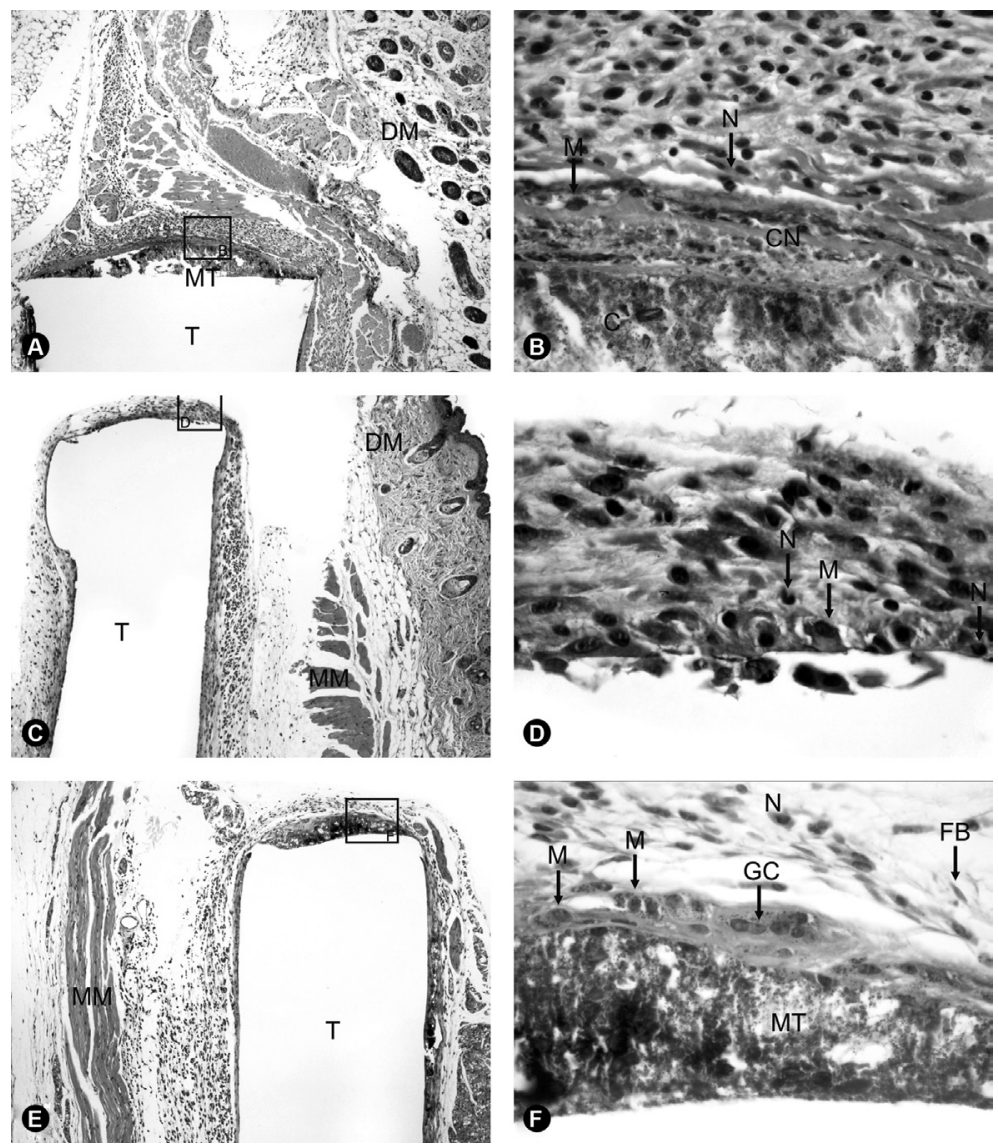

Figure 2. Sealapex Sealer: A and B = At 7 days, there is great amount of material, macrophages (M) located more peripherally, few fibroblasts organized in thin bundle (in A) and polymorphonuclear neutrophils $(\mathrm{N})$ localized mainly at the interface with the material. There areas of coagulation necrosis $(\mathrm{CN})$ at the interface with the material. Crystalloid structures $(\mathrm{C})$ can be seen within the material. (HE; $\mathrm{A}=\times 4$ and $\mathrm{B}=\times 100$ ). $\mathrm{C}$ and $\mathrm{D}=\mathrm{At} 21$ days, there is mild collagen fiber formation with short collagen bundles permeated among the fibroblasts and capsular organization far from the material. Macrophages (M) can be seen among the fibroblasts as well as mild edema (represented by the spaces negative) and scarce polymorphonuclear neutrophils $(\mathrm{N})$. Macrophages and fibroblasts are the most frequent cells at the interface with the material. ( $\mathrm{HE} ; \mathrm{C}=\times 4$ and $\mathrm{D}=\times 100$ ). $\mathrm{E}$ and $\mathrm{F}=\mathrm{At} 63$ days, there is well organized, moderate collagen fiber formation, with well characterized fibroblasts (FB) in contrast with the exuberant giant cells (GC). The macrophages (M) immediately in contact with the material presented engulfed sealer particles in their cytoplasm. Occasional polymorphonuclear neutrophils $(\mathrm{N})$ are seen $(\mathrm{HE} ; \mathrm{E}=\times 4$ and $\mathrm{F}=\times 100)$. $\mathrm{T}=$ Polyethylene tube; $\mathrm{MT}=$ Material; $\mathrm{MM}=\mathrm{Skeletal}$ muscle; DM=Dermis. 
there was significant difference only between the control and Calen/ZO, and between the control and Sealapex $(p<0.05)$, the control presenting the largest area and Calen/ZO the smallest. At the 21-day period, the area of the reactionary tissue decreased in the control and in all tested materials, without statistically significant difference among the groups ( $p>0.05)$. At 63 days, the area decreased even more for Calen/ZO and Sealapex, and increased for ZOE. There was significant difference $(p<0.05)$ between Calen/ZO and ZOE, and between Sealapex and ZOE.

Regarding the greatest thickness of the RGT (Table 1), at 7 days there was no significant difference (p>0.05) among the groups. At the 21-day period, the thickness of the reactionary tissue increased in response to all tested materials and decreased in the control group. There was significant difference between ZOE and the control, and between Calen/ZO and the control $(p<0.05)$. At 63 days, there was no statistically significant difference ( $p>0.05)$ among the groups.

\section{DISCUSSION}

Since the toxic and inflammatory reactions present the same characteristics in all connective tissues (15-17), implants in subcutaneous connective tissue are used to evaluate the biological response to the implanted material (14), being a preliminary source of information
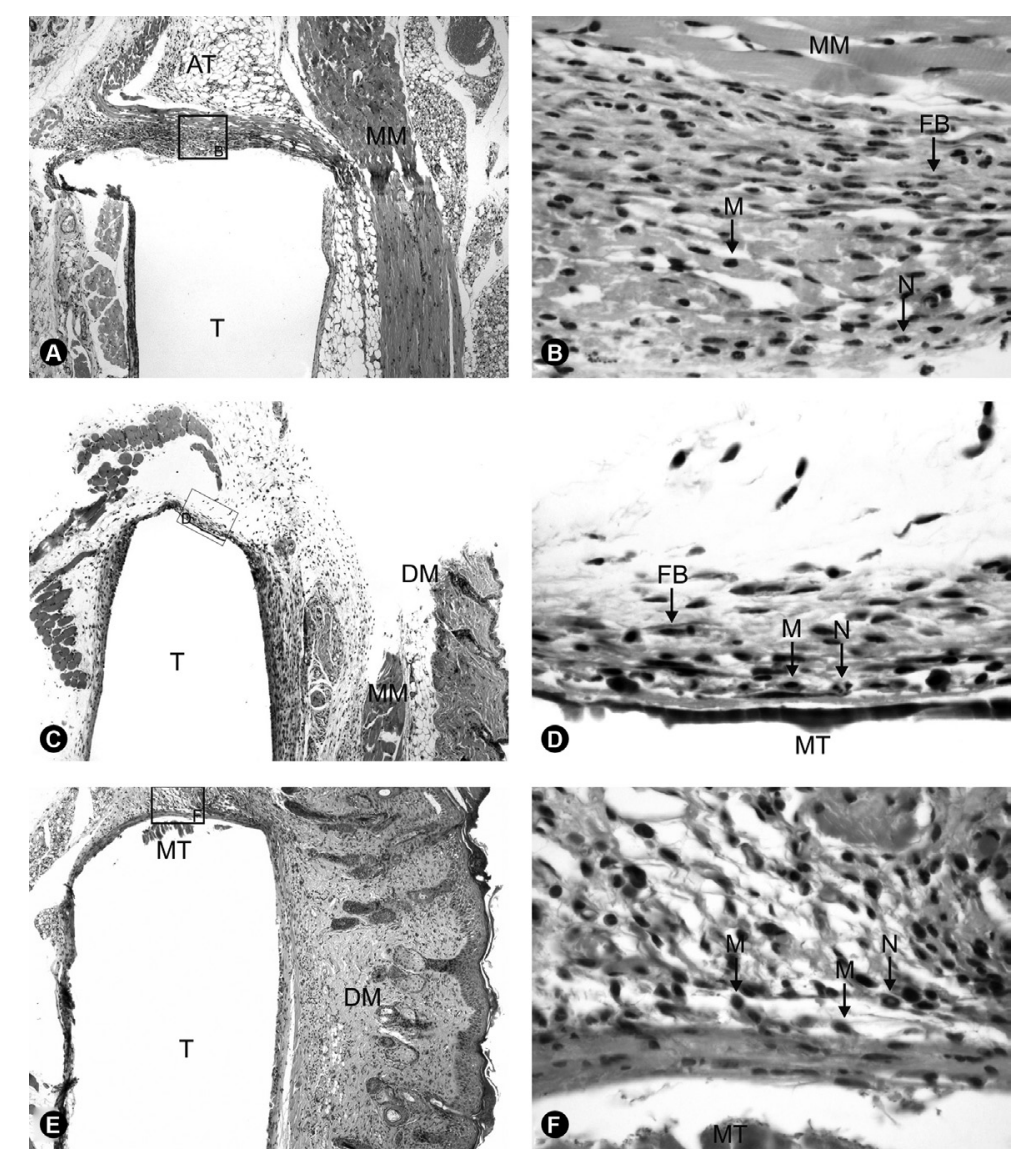

Figure 3. ZOE: A and B = At 7 days, no material fragments are observed. Macrophages $(\mathrm{M})$ and neutrophils $(\mathrm{N})$ are present at interface with the material. The fibroblasts (FB) are well organized in bundles (in A). The reactionary tissue is directly related with the skeletal muscle (MM). (HE; $\mathrm{A}=\times 4$ and $\mathrm{B}=\times 100)$. $\mathrm{C}$ and $\mathrm{D}=\mathrm{At} 21$ days, the reactionary tissue is thin and with good capsular organization. The fibroblasts (FB) are well defined, with spindle shape and continuously arranged with the thin collagen fibers. There is a small number of polymorphonuclear neutrophils $(\mathrm{N})$, and macrophages $(\mathrm{M})$ and occasional giant cells can be seen at the interface with the material (HE; $\mathrm{C}=\times 4$ and $\mathrm{D}=\times 100$ ). $\mathrm{E}$ and $\mathrm{F}=\mathrm{At} 63$ days, the collagen fibers formed at the interface with the material are thin and well organized. However, at the periphery with the adjacent tissues, their density and organization resembles a continuous fiber-rich connective tissue. Macrophages $(\mathrm{M})$ and polymorphonuclear neutrophils $(\mathrm{N})$ can be seen permeating this tissue $(\mathrm{HE} ; \mathrm{E}=\times 4$ and $\mathrm{F}=$ $\times 100$ ). $\mathrm{T}=$ Polyethylene tube; $\mathrm{MT}=$ Material; $\mathrm{AT}=$ Adipose tissue; $\mathrm{MM}=$ Skeletal muscle; $\mathrm{DM}=\mathrm{Dermis}$. 
about the compatibility of the material with the biological activity of the surrounding tissues.

In the present study, the inflammatory infiltrate, the area and the thickness of the reactionary tissue produced by Calen/ZO decreased with time, showing collagen fiber formation at the interface with the implanted material.

The Calen paste is a recognizably biocompatible material $(9,10)$, being used as a temporary dressing in teeth with periapical lesions (18). However, although Calen/ZO presents high antimicrobial activity (13), its tissue compatibility has not been evaluated in previous studies, which makes difficult the direction discussion of the present results.

Although some authors have attributed to the zinc the capacity of interfering in the inflammatory process for reducing phagocytic capacity of macrophages and interfere in the membrane of the lysosomes (19), the incorporation of ZO to the Calen paste seems not to have affected its biological proprieties, since in the present study, after implantation of the polyethylene tubes containing Calen/ZO in the subcutaneous connective

Table 1. Means (and standard deviation) of the area and greatest thickness of reactionary granulomatous tissue (RGT).

\begin{tabular}{|c|c|c|c|c|c|c|}
\hline \multirow[t]{2}{*}{ Material } & \multicolumn{3}{|c|}{ Area of RGT $\left(\mu \mathrm{m}^{2}\right)$} & \multicolumn{3}{|c|}{ Greatest thickness of RGT $(\mu \mathrm{m})$} \\
\hline & 7 days & 21 days & 63 days & 7 days & 21 days & 63 days \\
\hline Calen/ZO & $49.7(10.95)$ & $33.33(8.396)$ & $29.42(8.411)$ & $359.1(103.3)$ & $399.2(74.86)$ & $221.8(32.05)$ \\
\hline Sealapex & $51.80(9.475)$ & $43.44(8.877)$ & $30.38(8.768)$ & $298.0(87.47)$ & $325.9(79.58)$ & $171.5(52.56)$ \\
\hline $\mathrm{ZOE}$ & $61.30(11.17)$ & $45.33(10.15)$ & $51.85(11.32)$ & $354.7(138.2)$ & $390.0(44.71)$ & $235.2(57.61)$ \\
\hline Control & $67.81(4.365)$ & $36.26(1.062)$ & - & $353.3(4.314)$ & $216.6(75.72)$ & - \\
\hline
\end{tabular}

Calen $/ \mathrm{ZO}=$ Calen paste thickened with zinc oxide; $\mathrm{ZOE}=$ Zinc oxide and eugenol cement.
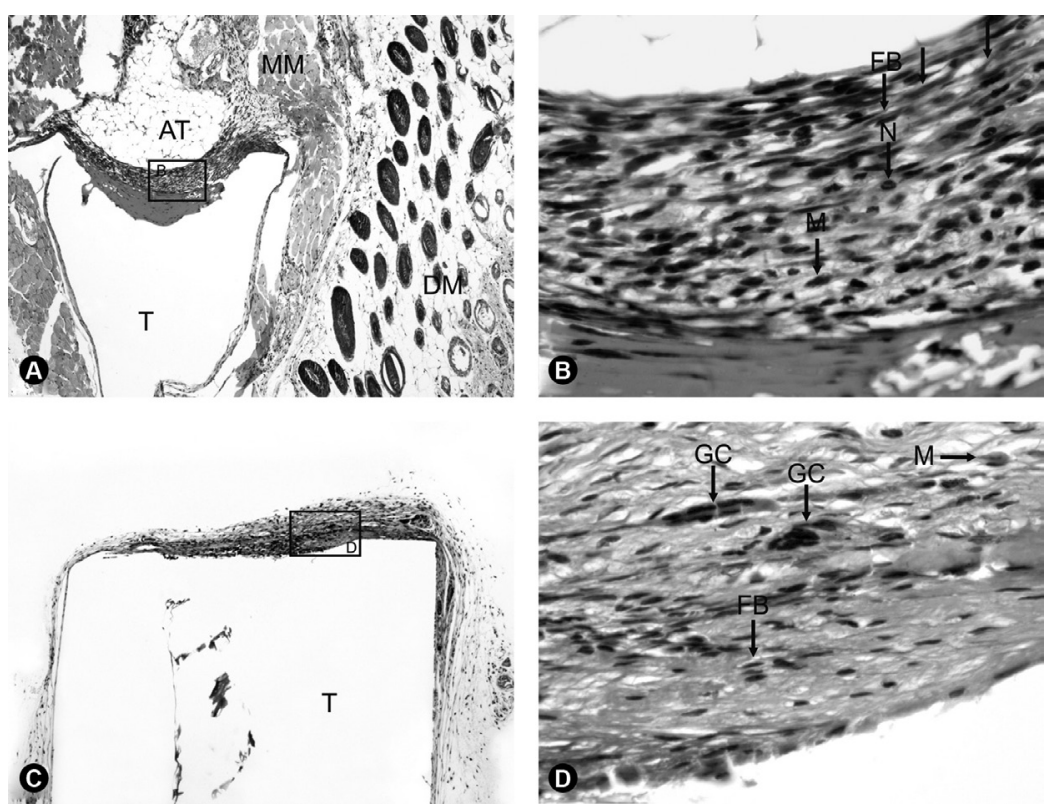

Figure 4. Empty polyethylene tube: $\mathrm{A}$ and $\mathrm{B}=\mathrm{At} 7$ days, the reactionary tissue at the tube end is moderately thick, but rich in fibroblasts (FB) and macrophages (M). There is mild inflammatory infiltrate, characterized by the presence of few polymorphonuclear neutrophils (N). Mild and well organized collagen fiber formation is observed (arrows in B). Inflammatory exudate is present in the tube lumen ( $\mathrm{HE} ; \mathrm{A}=\times 4$ and $\mathrm{B}=\times 100$ ). $\mathrm{C}$ and $\mathrm{D}=\mathrm{At} 21$ days, moderately thick reactionary tissue is seen at the tube end, with mild collagen fiber formation and moderated number of fibroblasts $(\mathrm{FB})$ permeated by macrophages $(\mathrm{M})$, in addition to occasional polymorphonuclear neutrophils and giant cells $(\mathrm{GC})$. The tissue at the empty tube end is thicker and richer in inflammatory cells compared to the tissue at the lateral tube walls (in $\mathrm{C})$. (HE; $\mathrm{C}=\times 4$ and $\mathrm{D}=\times 100)$. $\mathrm{T}=$ Polyethylene tube; $\mathrm{MM}=$ Skeletal muscle; $\mathrm{AT}=\mathrm{Adipose}$ tissue; $\mathrm{DM}=\mathrm{Dermis}$. 
tissue of mice showed compatibility with the biological activity of peripheral tissues.

In the group in which polyethylene tubes filled with Sealapex were implanted, an intense inflammatory infiltrate was observed at the beginning of the experiment, which, although decreased in the intermediate period, was exacerbated at 63 days. Over time, the collagen fiber formation increased and the area and thickness of the reactionary tissue decreased.

After implantation of the tubes containing Sealapex in the connective tissue of subcutaneous rats, Zmener et al. (15) observed, after 7 days, the formation of a granulomatous reactionary tissue containing GC and macrophages with material particles engulfed in their cytoplasm, as well as several fibroblasts and blood vessels. The area of tissue reaction to the implant increased with time and the presence of material particles
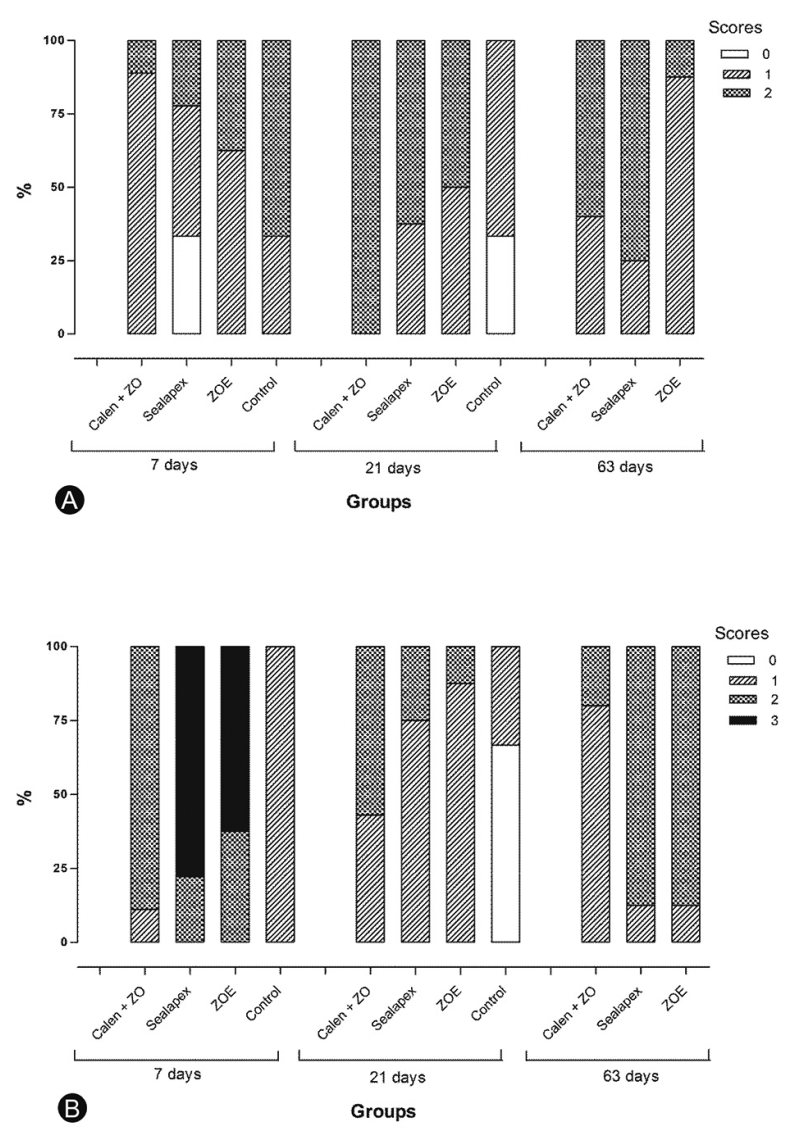

Figure 5. Score distribution in the groups regarding collagen fiber formation (A) and inflammatory infiltrate (B) in the different groups. Mean values and standard deviations of the area (C) and greater thickness (D) of the reactionary granulomatous tissue formed at the tube end of all groups. inside the macrophages, GC and vessels, far from the tube ends. According to the authors, this fact is due to components of Sealapex, such as titanium dioxide, which may be easily dispersed by the adjacent tissues, causing an intense foreign body tissue reaction.

Unlike the findings of Zmener et al. (15), the present results showed that the area of granulomatous reactionary tissue to the implanted polyethylene tubes containing Sealapex decreased with time. However, in the same way as observed by those authors, we found macrophages and GC diffusively distributed in the reactionary tissue, with material particles in their cytoplasm, demonstrating the presence of a material that the organism finds hard to break down. In addition, Zmener et al. (15) did not mention the presence of PMN, which, in the present experiment, were observed in all periods, with a larger number of these cells at 63 days in comparison to 21 days. It may be speculated that this intensification of the PMN response is related to the solubilization of the sealer and the release of more aggressive products, present in their new formulation, which exacerbate the inflammatory tissue reaction.

The tissue reaction after implantation of the tubes containing Sealapex in the subcutaneous connective tissue of rats was evaluate in a previous study (6), which found that good tissue tolerance. In the present investigation, collagen fiber formation became more defined with time and. At 63 days, the fibrous capsule was well organized, and there were macrophages and $\mathrm{GC}$ with birefringent material in their cytoplasm.

Veloso et al. (7) implanted polyethylene tubes filled with Sealapex in the subcutaneous tissue of rats and observed that in the initial periods ( $48 \mathrm{~h}$ and 7 days), the inflammatory response ranged from severe to moderate, and at the final periods ( 21 and 60 days), the tissue reactions were becoming less intense, demonstrating the biocompatibility of this sealer. In the present study, it was also observed the presence of inflammatory infiltrate ranging from moderate to severe in the initial period, and was predominantly mild at 21 days and predominantly moderate at 63 days.

The reaction of the connective tissue of rats to Sealapex has also been evaluated by the implantation of tubes into the dorsal connective tissue of Wistar rats in a previous study (8). The material caused mild or moderate inflammatory reactions on the 7 th day, but these reactions decreased by the 30th day, which was also observed in the present study.

Regarding ZOE, Sumer et al. (16), after 
implantation of tubes containing ZOE in the subcutaneous connective tissue of rats observed a discrete inflammatory response at 15, 30 and 60 days. In the present experiment, predominantly mild inflammatory infiltrate was observed only at 21 days, being severe at 7 days and moderate at 63 days. The 7 -day findings indicate that the inflammatory process was in the initial stage and that at 63 days the aggression was occurring in a repetitive manner. A severe tissue response in the initial periods is predictable, but not in the final periods (16).

Although ZOE is still widely used for obturation of root canals of primary teeth $(1,5)$, other materials with potentially greater tissue compatibility are available. In the present study, Calen/ZO presented the best tissue response compared to Sealapex and ZOE.

\section{RESUMO}

Neste estudo avaliou-se a resposta do tecido conjuntivo subcutâneo de camundongos BALB/c a materiais obturadores de canal radicular de dentes decíduos: óxido de zinco/eugenol (OZE), pasta Calen ${ }^{\circledR}$ espessada com óxido de zinco (Calen/OZ) e cimento Sealapex ${ }^{\circledR}$. Os camundongos $(n=102)$ receberam implantes de tubos de polietileno+material e foram divididos em grupos: I, II, III - Calen/OZ (7, 21 e 63 dias, respectivamente); IV, V, VI Sealapex (7, 21 e 63 dias, respectivamente); VII, VIII, IX - OZE (7, 21 e 63 dias, respectivamente); X, XI - tubo vazio (7 e 21 dias, respectivamente). Os tecidos foram submetidos ao processamento e análise histopatológica descritiva e por meio de escores do fibrosamento, espessura tecidual e infiltrado inflamatório. Para a análise quantitativa mensurou-se a área e a espessura do tecido granulomatoso reacional (TGR). Os resultados foram analisados pelos testes de Kruskal-Wallis, ANOVA e pós-teste de Tukey $(\alpha=0,05)$. Não houve diferença significante $(p>0,05)$ entre os materiais, com relação ao fibrosamento e à espessura do TGR. Contudo, Calen/OZ apresentou infiltrado inflamatório de menor intensidade $(p<0,05)$. A área do TGR foi menor $(p<0,05)$ para Calen/OZ e Sealapex. Pôde-se concluir que Calen/OZ foi o material que apresentou a melhor compatibilidade tecidual, seguido pelos cimentos Sealapex e OZE.

\section{REFERENCES}

1. American Academy of Pediatric Dentistry Clinical Affairs Committee - Pulp Therapy Subcommittee; American Academy of Pediatric Dentistry Council on Clinical Affairs. Guideline on pulp therapy for primary and young permanent teeth. Pediatr Dent 2005-2006;27(7 Suppl):130-134.

2. Woods RL, Kildea PM, Gabriel SA, Freilich LS. A histologic comparison of Hydron and zinc oxide-eugenol as endodontic filling materials in the primary teeth of dogs. Oral Surg Oral Med Oral Pathol 1984;58:82-93.

3. Sari S, Okte Z. Success rate of Sealapex in root canal treatment for primary teeth: 3-year follow-up. Oral Surg Oral Med Oral Pathol Oral Radiol Endod 2008;105:e93-e96.
4. Johnson MS, Britto LR, Guelmann M. Impact of a biological barrier in pulpectomies of primary molars. Pediatr Dent 2006;28:506-510.

5. Primosch RE, Ahmadi A, Setzer B, Guelmann M. A retrospective assessment of zinc oxide-eugenol pulpectomies in vital maxillary primary incisors successfully restored with composite resin crowns. Pediatr Dent 2005;27:470-477.

6. Molloy D, Goldman M, White RR, Kabani S. Comparative tissue tolerance of a new endodontic sealer. Oral Surg Oral Med Oral Pathol 1992;73:490-493.

7. Veloso HH, Santos RA, Araújo TP, Leonardi DP, Baratto Filho F. Histological analysis of the biocompatibility of three different calcium hydroxide-based root canal sealers. J Appl Oral Sci 2006;14:376-381.

8. Gomes-Filho JE, Bernabé PF, Nery MJ, Otoboni-Filho JA, DezanJúnior E, de Moraes Costa MM, et al.. Reaction of rat connective tissue to a new calcium hydroxide-based sealer. Oral Surg Oral Med Oral Pathol Oral Radiol Endod 2008;106:e71-76.

9. Nelson Filho P, Silva LA, Leonardo MR, Utrilla LS, Figueiredo F. Connective tissue responses to calcium hydroxide-based root canal medicaments. Int Endod J 1999;32:303-311.

10. Leonardo MR, Hernandez ME, Silva LA, Tanomaru-Filho M. Effect of a calcium hydroxide-based root canal dressing on periapical repair in dogs: a histological study. Oral Surg Oral Med Oral Pathol Oral Radiol Endod 2006;102:680-685.

11. Silva RA, Assed S, Nelson-Filho P, Silva LA, Consolaro A. Subcutaneous tissue response of isogenic mice to calcium hydroxide-based pastes with chlorhexidine. Braz Dent J 2009;20:99-106.

12. Silva LAB. Tratado de Odontopediatría. 1st ed. Venezuela: Amolca; 2008.

13. Queiroz AM, Nelson-Filho P, Silva LA, Assed S, Silva RA, Ito IY. Antibacterial activity of root canal filling materials for primary teeth: zinc oxide and eugenol cement, Calen paste thickened with zinc oxide, Sealapex and EndoREZ. Braz Dent J 2009;20:290-296.

14. International Standard ISO 10993-6. Biological evaluation of medical devices- Part 6: Tests for local effects after implantation. 1994:1-11.

15. Zmener O, Guglielmotti MB, Cabrini RL. Biocompatibility of two calcium hydroxide-based endodontic sealers: a quantitative study in the subcutaneous connective tissue of the rat. J Endod 1988;14:229-235.

16. Sumer M, Muglali M, Bodrumlu E, Guvenc T. Reactions of connective tissue to amalgam, intermediate restorative material, mineral trioxide aggregate, and mineral trioxide aggregate mixed with chlorhexidine. J Endod 2006;32:1094-1096.

17. Zafalon EJ, Versiani MA, de Souza CJ, Moura CC, Dechichi P. In vivo comparison of the biocompatibility of two root canal sealers implanted into the subcutaneous connective tissue of rats. Oral Surg Oral Med Oral Pathol Oral Radiol Endod 2007;103:e88-e94.

18. Herrera H, Herrera H, Leonardo MR, de Paula e Silva FW, da Silva LA. Treatment of external inflammatory root resorption after autogenous tooth transplantation: case report. Oral Surg Oral Med Oral Pathol Oral Radiol Endod 2006;102:e51-e54.

19. Economides N, Kotsaki-Kovatsi VP, Poulopoulos A, Kolokuris I, Rozos G, Shore R. Experimental study of the biocompatibility of four root canal sealers and their influence on the zinc and calcium content of several tissues. J Endod 1995;21:122-127.

20. Scarparo RK, Grecca FS, Fachin EV. Analysis of tissue reactions to methacrylate resin-based, epoxy resin-based, and zinc oxideeugenol endodontic sealers. J Endod. 2009;35:229-232.

Accepted April 4,2011 